\title{
THE DANCE OF THE ANGELS, THE MYSTERIES OF \\ PSEUDO-DIONYSIUS AND THE ARCHITECTURE \\ OF GOTHIC CATHEDRALS
}

The bliss of heaven has been characterised by the dance of the angels and the illumination of light. The dance of the angels was commonly depicted on church ceilings and in Medieval and Renaissance paintings. An example of this is the dance of the angels and the blessed from Angleo da Fiesle's 'Last Judgement' painted in 1425 in the collection of the Academia della Belle Arte in Florence. Clement of Alexandria claimed that with the revelation of the Christian mysteries the initiated shall dance with the angels.' In Medieval hymns there are numerous references to the ring dance of angels or the virgins. ${ }^{2}$ The spheres of Dante's Paradise are full of light, music and dance, with the exception of the sphere of Saturn, which was the sphere of contemplation. In the sphere of the sun, the souls of the wise and learned performed a ring dance that encircled Dante and Beatrice. The ethereal light, harmony and the bliss of heaven radiated from this dance of the souls.' In Pseudo-Dionysius's 'Celestial Hierarchy' the nine spheres of angels dance a celestial choral dance. The angels' task was to receive and to pass on the divine light, and through this illumination comes the understanding that brings perfection.' Cosmic dance became linked with the Christian mysteries of baptism and the Eucharist.

Pseudo-Dionysius's Ecclesiastical Hierarchy was patterned on the Celestial Hierarchy. The direct connection of the corporeal world to the incorporeal world was the mysteries. However, the mysteries were much more than just a connection with the invisible world they gave the incorporeal world their shape or pattern in the corporeal world. This paper examines these patterns. First, through an examination of the connection of dance and the mysteries, from Philo Judaeus to PseudoDionysius, circa fifth century; second through the influences of Pseudo Dionysius in the designs of the Gothic cathedrals and the patterns and designs they contain within.

\section{PHILO, THE CHORAL DANCE OF GENESIS AND THE THERAPEUTICS}

Philo Judaeus (c. 20 BC-c. 40 AD) was a Jewish philosopher, born in Alexandria. Little is known of Philo's life, although, he was Jewish in religion, Greek by tradition, and Roman citizen by the necessity of the times. In c. 39-40 AD he was sent to Rome as a part of an embassy to the Emperor Caligula to protest against the persecution which the Jews had suffered in Alexandria at the hands of the Romans.' The date of his death is uncertain, but it is known that his life-span covers the life times of Jesus, John the Baptist and much of St. Paul, although there is no mention of them in any of his many works.' However, Eusebius claimed that tradition says that Philo came to Rome in the time of Claudius to speak to Peter.'

In Philo's 'On the Account of the World's Creation Given by Moses' 8 he employed Pythagorean numerology to untangle the hidden meaning of the numbers in the book of Genesis. He explained the properties of the numbers of the decad, ten, 
but it was the numbers four and seven that captured Philo's imagination. Four contains the ratios of the musical consonances, which produce the interval of harmonies, the ratios $1: 2,4: 3,3: 2,4: 1{ }^{9}$ Four has interesting arithmetical properties such as the addition of two plus two equals two times two, which equals four." The universe was fashioned by four elements and there are four seasons." It was on the fourth day that God created the heavenly bodies, the planets, that gave the universe light and music, and the harmony of the spheres.'

Right through Philo's writing he creates cyclic patterns; the number four was the day of the creation of the planets, which gave light and created the four seasons; it gave music, which can be expressed by ratios made up of the digits that are contained in four. To Philo, light, which is created by the heavenly bodies, was the source of all the harmonies, rhythmic dance, time and number." The universe was made in the image of the pattern of God's Mind and man was created after the image of God. The human mind "when on soaring wing it has contemplated the atmosphere and all its phases, it is borne yet higher to the ether and the circuit of heaven, and is whirled round with dances of planets and fixed stars, in accordance with the laws of perfect music, following that love of wisdom which guides its steps. And so, carrying its gaze beyond the confines of all substance discernible by sense, it comes to a point at which it reaches out after the intelligible world, and on decrying in the world sights of surpassing loveliness, even the patterns and the originals of the things of sense which it saw here, it is seized by a sober intoxication, like those filled with Corybantic frenzy, and is inspired, possessed by a longing for other than theirs and noble desire."' The mind soars dancing through the celestial spheres to the topmost arch of the things perceptible to the human mind, seemingly on its way to God. However, not always correspond to their patterns.15 The circling and the most wondrous movements of the heavens was always in perfect proportion of numbers and harmony of revolutions were the real music, the original music. From the music of the spheres men modelled their own music through the subsequent ages and they painted the images in their own souls handed down in art. ${ }^{16}$

Philo expanded upon on the properties of the number seven. After six days of creation God declared the seventh day holy. ${ }^{17}$ Seven has many arithmetical properties that Philo expanded on. Every organic being has seven properties; length, breadth, depth, point, line, surface and solid. ${ }^{18}$ They are seven stages of life, ${ }^{19}$ seven planets and seven harmonies of the spheres. ${ }^{20}$ There are seven strings on the lyre to correspond to the choir of the planets. ${ }^{21}$ The number seven dominates nature and only one thing can be the cause of motion and that is God, symbolised by the number seven. ${ }^{22}$ "There are seven movements: upward, downward, to the right, to the left, forward, backward, in a circle. These come out most distinctly in an exhibition of dance." ${ }^{23}$ The cosmic dance and the harmony of the spheres were used or regarded as models by men, in number, in sound, and in movement, even if the image and the pattern are different, since images do not always correspond the their patterns. ${ }^{24}$

Philo also left an account of a community, called the Therapeutics, in a treatise 
called 'The Contemplative Life'. ${ }^{25}$ The Therapeutics was an ascetic community both male and female, ${ }^{26}$ who had settled around Alexandria. ${ }^{27}$ They had relinquished their property and family for a life of solitude and contemplation. ${ }^{28}$ Their name Therapeutae derived from the fact that they professed an art of healing, not only of bodies but also of souls. ${ }^{29}$ They lived a very austere life, spending most of their time meditating the Scriptures, in devotional works, praying and composing hymns. ${ }^{30}$ Every seventh day, they came together in a general assembly, to listen to a sermon, with the men and women sitting in separate sections of the building. ${ }^{31}$ However, after seven sets of seven days the people assembled for a festive meeting, "for they revere not only the simple seven but its square also, since they know its chastity and perpetual virginity.",32

After feasting they came together to hold a sacred vigil in the middle of the refectory. First, they formed two choirs, one of women and one of men. "Then they sing hymns to God composed of many measures and set to many melodies, sometimes chanting together, sometimes taking up the harmony antiphonally, hands and feet keeping time in accompaniment, and rapt with enthusiasm reproduce sometimes the lyrics of the procession, sometimes of the halt and of the wheeling (strophe) and counterwheeling (antistrophe) of a choric dance." ${ }^{33}$ The Therapeutics came together after seven sets of seven days to praise the creator, to sing and dance a circular dance of a tripartite structure; strophe - turn, antistrophe - counter-turn and halt. They danced until dawn, then they turned to the east to see the sunrise, with hands stretched up to the heaven, and prayed for knowledge of the truth, ${ }^{34}$ of the revelations of the mysteries.

Eusebius, Bishop of Caesarea (c. 264-340 AD), claimed that the Therapeutics were the first converts to Christianity. ${ }^{35}$ Eusebius appeared to be quite convinced that the rituals and the great feast of the Therapeutics, that Philo described, were Early Christian. He claimed that "Philo perceived and described the first heralds of the teaching according to the Gospel and the customs handed down from the beginning by the Apostles." ${ }^{36}$ Moreover, he claimed that it was clear that the men of the Therapeutics were devoted Jews of the Apostolic age, not Early Christians. ${ }^{37}$ To Eusebius such a circular dance of a tripartite structure performed at the feast was an acceptable ritual for Christians.

\section{THE HYMN OF JESUS IN THE ACTS OF ST. JOHN}

In the Acts of St John chapters 94 to 102 a round dance of the disciples led by Jesus was described. John was reported to have been the same author of the fourth Gospel, the book of Revelation, and the three epistles of John. ${ }^{38}$ However, Biblical criticism has identified three or four distinct styles of individuals named John. ${ }^{39}$ The Acts of St John is imprecisely dated c. 100-300 $\mathrm{AD}^{40}$ and remained outside the later mainstream of Catholic doctrinal thought.

The Acts described a ritual dance performed on the evening before the Martyrdom of Jesus. Jesus bade his disciples to form a ring holding one another's hands while he stood in the middle. He began to sing a hymn: 
"Glory be to thee, Father.

And we (the disciples), going about in a ring, answered him: Amen

Glory be to thee, Word: Glory be to thee Grace. Amen.

Glory be to thee, Spirit: Glory be to thee, Holy One:

Glory be to thy glory. Amen

We praise thee, O Father; we give thanks to thee,

O Light, wherein darkness dwelleth not. Amen

Now whereas we give thanks I say:

I would be saved, and I would save. Amen.

I would be loosed, and I would loose. Amen.

I would be wounded, and I would wound. Amen.

I would be born, and I would bear. Amen.

I would eat, and I would be eaten. Amen.

I would hear, and I would be heard. Amen.

I would be thought, being wholly thought. Amen.

I would be washed, and I would wash. Amen.

Grace danceth. I would pipe; dance ye all. Amen.

I would mourn: lament ye all. Amen.

The number Eight singeth praise with us. Amen.

The number Twelve danceth on high. Amen.

The Whole on high bath part in our dancing. Amen.

Whoso danceth not, knoweth not what cometh to pass. Amen

I would flee, and I would stay. Amen.

I would adorn, and I would be adorned. Amen.

I would be united, and I would unite. Amen.

A house I have not, and I have houses. Amen.

A place I have not, and I have places. Amen.

A temple I have not, and I have temples. Amen.

A lamp am Ito thee that beholdest me. Amen.

A mirror am I to thee that perceivest me. Amen.

A door am Ito thee that knockest at me. Amen.

Away am Ito thee a wayfarer. Amen.

Now answer thou unto my dancing. Behold thyself in me who speak, and seeing what I do, keep silence about my mysteries." 41

The hymn described the whole of creation. ${ }^{42}$ The number Eight that is singing praise with the disciples represent the harmonies of the spheres, from the seven planets and the fixed stars. The number Twelve that danced on high represents the twelve zodiac signs. The 'Whole' on high is the universe, and whoever does not dance will not understand the mysteries. This celestial dance circles around Jesus who was playing the pipe and singing in the centre. In the Acts of St John, the hymn of Jesus was the Eucharist and thus understood as the mysteries. ${ }^{43}$ In the Gospels, both Mathew and 
Mark mention a hymn sung after the wine and bread had been consumed at the Last Supper, i.e. the first Eucharist. "And when they had sung a hymn, they went out into the Mount of Olives" (Mathew 26:30; Mark 14:26). However, there is no mention of any such hymn in the Gospel of John.

The hymn begins with an eightfold formula of praise, followed by an eightfold formula of being and actions. Within the later eightfold formula are lines that appear to refer directly to the first Eucharist; "I would eat, and I would be eaten." At the Last Supper "as they were eating, Jesus took bread, and blessed it, and brake it, and gave it to the disciples, and said, Take, eat; this is my body" (Matthew, 26:26). Also at the Last Supper, Jesus after washing himself washes the feet of the disciples (John, 13:4-12). "I would be washed and I would wash." Furthermore eight is the number that symbolises the resurrection.

The Hymn of Jesus and other passages in the Acts of St John are Gnostic in origin. ${ }^{44}$ The Greek word gnosis translated to 'esoteric knowledge' and the Gnostics were a Christian movement that claimed to know secret mysteries kept hidden from the masses. This early Gnostic-Christian round dance and hymn enact a sacred ritual dance. The Acts of St John claimed that the cross of light sometimes referred to as 'the Word' would bring stability "out of things unstable, and the harmony of wisdom and indeed wisdom in harmony." 45 It will bring the universal stability of the heavens, and the understanding of the harmonies and choral dance of the spheres. Christ has suffered on the cross "that suffering also which I showed unto thee and the rest in the dance, I will that it be called a mystery." 46

Augustine. Bishop of Hippo (354-430 AD), condemned the Acts of St John as heresy. He claimed in a letter to Ceretius, a Spanish or Gallic bishop, that true Christians could not read this hymn with any pleasure since it portrayed Christ as a piping fool who "has made sport of all things". ${ }^{47}$ In the fifth century Pope Leo the Great strongly denounced the hymn as heresy. He decreed that such writings "which contain a hotbed of manifold perversity, should not only be forbidden but altogether removed and burnt with fire." ${ }^{48}$ Excerpts of the Acts of St John, including the Hymn of Jesus where read aloud at the second Council of Nicaea held in 787 AD, they were condemned as being ludicrous writings. ${ }^{49}$ Despite these condemnations the Acts of St John survived after being copied secretly by Christians who risked heresy.

In Clement of Alexandria's 'Exhortation of the Greeks' he claimed "I will show thee the Word, and the Word's mysteries, describing them according to thine own semblance of them." ${ }^{50}$ Clement berates the drunkenness, frenzy-stricken revellers of the Bacchic rites. These revellers such cast of their fawnskins and return to soberness and be led by the hand to the truth. ${ }^{51}$ The mysteries of the Bacchic rites or any of the pagan mysteries are not the true mysteries. The true and sacred mysteries of pure light given to the initiated reveal visions of heaven and of God. "These are the revels of the mysteries! If thou wilt, be thyself also initiated, and thou shalt dance with the angels around the unbegotten and imperishable and only true God, the Word of God joining with us in our hymn of praise. ${ }^{52}$ This image of dancing angels in celebration around the 
altar, the manger, Joseph and Mary, or God, became popular in the Medieval and Renaissance art such as Botticelli's 'Supplication Dance of the Shepherds' and famous literary works such as Dante's Divine Comedy. While the image of the disciples dancing around the piper Jesus was an unacceptable image to the Church Fathers, the celestial dancers appear to have been more acceptable and revered.

Neither the hymn of Jesus in the Acts of St John nor the dance of the angels of Clement give details of the structure of the dance; except insofar as both are round, there was no mention of the tripartite structure. However, both are celestial dances: the hymn of Jesus embodies the corporeal cosmos, while Clement embodies the incorporeal cosmos. The Dancer, who dances with the universe and hears the harmonies of the sphere, will understand the mysteries, while in Clement, joining the dance of the angels is the result of having the mysteries revealed. The Christian mysteries, baptism and the Eucharist, were becoming linked with cosmic dance and certainly religious celebration and initiation.

\section{PSEUDO-DIONYSIUS, THE ECCLESIASTICAL HIERARCHY AND THE MYSTERY OF THE SYNAXIS}

The 'Celestial Hierarchy' and the 'Ecclesiastical Hierarchy' were two most influential books in the Medieval Age. In religious history, the author was one Dionysius the Areopagite, an Athenian convert of St Paul mentioned in Acts 17:34. In fact the author of these Greek neo-Platonists works was anonymous and the works were written in the fifth or sixth century. Consequently, he is now referred to as PseudoDionysius.

To Pseudo-Dionysius, God's illumination travelled down from the most exalted to the most humble. ${ }^{53}$ The illumination was passed down from God through the celestial hierarchy of the nine angelic spheres. The aim of every hierarchy was always to imitate God, and the task of every hierarchy was to receive and to pass on unadulterated purification of the divine light, and with this illumination came the understanding that brings perfection. ${ }^{54}$ The divine angels, first "move in a circle while they are at one with those illuminations which, without beginning and without end, emerge from the Good and the Beautiful. Then they move in a straight line when, out of Providence, they come to offer unerring guidance to all those below them. Finally they move in a spiral, for even while they are providing for these beneath them they continue to remain what they are and they turn unceasingly around the Beautiful and the Good from which all identity comes." ${ }^{55}$ As Paul said "From him, and through him, and to him, are all things: to whom be glory forever (Romans 11:36)."

The human or ecclesiastical hierarchy is the indispensable link between the incorporeal and corporeal worlds. The structure of the ecclesiastical hierarchy was based on the celestial hierarchy. It is a nine-fold hierarchy that imitates the choir of the angels. The direct connection of the visible world to the invisible world was the mysteries, or the sacrament. The mysteries were much more than just a connection with the invisible world: they gave the incorporeal world their shape or pattern in the 
corporeal world. The sacred symbols are used by the Holy Scriptures to reveal God. This metaphoric or symbolic language can appear to be incredible and filled with contrived fantasy. ${ }^{56}$ However, this symbolism does not exist for its own sake. This symbolism is "in order that the most sacred things are not easily handled by the profane but are revealed instead to the real lovers of holiness. ${ }^{57}$ The lover of holiness will transcend the truth of the symbols. These truths are inaccessible to the profane. The explanations of the divine mysteries are solely gained by way of the perceptible symbols attached to them and then only by believers - the 'truly' faithful. ${ }^{58}$ As Paul claimed, the invisible things of God are known by the visible things of the world (Romans 1:20). To Pseudo-Dionysius, the seeker of the divine Wisdom "must make the holy journey to the heart of the sacred symbols. ${ }^{59}$ The only way this journey could be undertaken and the symbols understood was through initiation into the divine mysteries.

The nine levels of the ecclesiastical hierarchy, as modelled on the celestial hierarchy, had a three-fold structure consisting of three divisions: the clergy, the laity and the unholy. The clergy consisted of the hierarchs or bishops, the priests and the deacons. The hierarch was the link between the incorporeal and corporeal worlds. The hierarch conducted the initiation into the holy rites and mysteries and performed the most sacred mystery, the Holy Eucharist. ${ }^{60}$ The purpose of the Holy Eucharist was to "pass the light of God onto the initiates."61 The priests are next in the hierarchy, they performed an important roll in the initiation into the Mysteries of the Church, and after this initiation the initiate could take part in the Holy Eucharist. ${ }^{62}$ The order of the deacons performed the purification of the initiate before they could partake in the sacred rites of the initiation. ${ }^{63}$ "The holy sacrament brings about purification, illumination, and perfection. The deacons form the order, which purifies. The priests constitute the order, which gives illumination. The hierarchs, living in conformity with God, make up the order which perfects. ${ }^{64}$

The laity consist of the monks, the sacred people and the initiated. Monks were sometimes called therapeutae because of their service and the purity of their duty. ${ }^{65}$ The monastic order was the highest degree of the laity. The sacred people were a contemplative order, they live a single-minded life of contemplation. ${ }^{66}$ Finally, initiated were those who had been initiated into the sacred mysteries and who partook in the Holy Eucharist. ${ }^{67}$

The unholy consisted of the penitents, the possessed and the Catechumens. The penitents were those who have been initiated into the sacred mysteries but have turned away from the illumination of God. ${ }^{68}$ The possessed have turned away from the divine example and have adopted the ideas of abominable demons - they are profane ${ }^{69}$ and have not received initiation. ${ }^{70}$ Finally the catechumens are the lowest of the hierarchy; "they are unready and unshaped like still-born fetuses." ${ }^{71}$ The uninitiated catechumens are completely without light; they also have not been initiated. ${ }^{72}$

The mystery of the illumination was performed so that the initiate could 
behold the divine symbols of the divine rebirth. The hierarch first received the initiate and his sponsor, then the hierarch began to sing hymns from the sacred scripture. Then the hierarch kissed the altar and asked why the initiate had come. The initiate confessed his ungodliness, his lack of knowledge of the truth and the divine life. After the initiates confession the man and his sponsor are enrolled. ${ }^{73}$ As the initiate was being stripped of his clothes by a deacon, the hierarch prayed. The naked initiate then faced west with hands outstretched in a gesture of rejection; Satan was rejected three times. Then he turned to the east, eyes to the heavens, hands outstretched, in a gesture of submission; and three times the initiate professes his faith to Christ. ${ }^{74}$ The priests anointed him with holy oil, while the hierarch blessed him three times with the sign of the cross. With sacred invocations the hierarch consecrated the water. A priest called out the name of the initiate from the roll and then led him to the water where he was again handed over to the hierarch. The hierarch immersed the initiate three times after each immersion and then invoked the Holy Trinity. ${ }^{75}$ The priest led the neophyte back to his sponsor, then back to the hierarch who declared that the neophyte was now worthy to participate in the most sacred holy Eucharist. ${ }^{76}$

Pseudo-Dionysius often calls the holy Eucharist the Synaxis, in the sense of a communion of the whole church in the most solemn act of worship. The Synaxis or Eucharist was the climax of the sacrament of the initiation. "Scarcely any of the hierarchic sacraments can be performed without the divine Eucharist as the high point of each rite, divinely bringing about a spiritual gathering to the One for him who receives the sacrament, granting him as a gift from God its mysteries perfecting capacities, perfecting in fact his communion with God."77 The mystery of the Synaxis began with the hierarch praying at the divine altar, he diffused incense while encircling the assembly. After returning to the altar the hierarch began to sing the sacred psalms. Then the deacons sung while other deacons stood guard to ensure the doors of this sacred place are closed so that the uninitiated do not enter. The hierarch said sacred prayers while the assembly exchanged a ritual kiss. The hierarch praised the sacred works of God and "sets about the performance of the most divine acts, and lifts into view things praised through the sacred displaced symbols." ${ }^{78}$ After receiving and distributing the divine Communion the hierarch concluded with the sacred thanksgiving.

The hierarch encircling the assembly was symbolic of the procession of illumination of God to the assembly. His return to the starting point symbolised unification, the hierarch "returns to its own inherent oneness, and confers unity on all those sacredly uplifted to it." ${ }^{79}$ Figure 1 shows the pattern of the procession, down from the altar and the upward return to the altar within a plan of a sixth century Byzantine church. Sacred hymns are sung, "they have attuned us to the divine harmony and have brought us into accord not only with divine realities but with our individual selves and with others in such a way that we make up one homogeneous choir of sacred men." ${ }^{80}$ The solemn encircling procession and return, of the hierarch, followed by the choir of sacred men, was symbolic of the dances of the angels that spread the illumination of God. This dance Pseudo-Dionysius described as a simple and ceaseless 
dance around an eternal knowledge of God. ${ }^{81}$ The aim of the celestial hierarchy was to imitate God, to take on His form, to receive and to pass on the divine light. ${ }^{82}$ The purpose of the Eucharist was to pass the light of God onto the initiated. ${ }^{83}$ This was through the hierarch, he was the link of the corporeal world to the incorporeal as the head of the hierarchy it was through him that the illumination of God would come.

However, it was the mystery, the performance of the sacred rite that made visible the representation of the works of God. The mysteries made it possible to be able to behold the sacred symbols of the divine rebirth. The presentation of Christ was the appearance of the wine and bread, which was symbolic of the Incarnation which made Christ a composite and visible being. ${ }^{85}$ To Pseudo-Dionysius the Eucharist was a sacrifice. It represented the sacrifice of Christ, his crucifixion on the cross and the climax of the work of Christ. ${ }^{86}$ It was the sedate choral dance of the hierarch that made visible the mystical meaning of the universe and the illumination of God. The perceptible structure of the hierarch's dance was one complete circle, however the conceptual structure was the tripartite structure of the choral dance of the angels. To Pseudo-Dionysius the concepts of God could only be understood through perceptual symbolism. Perceptual symbolism of Christianity became strongly defined with the development of Christian architecture.

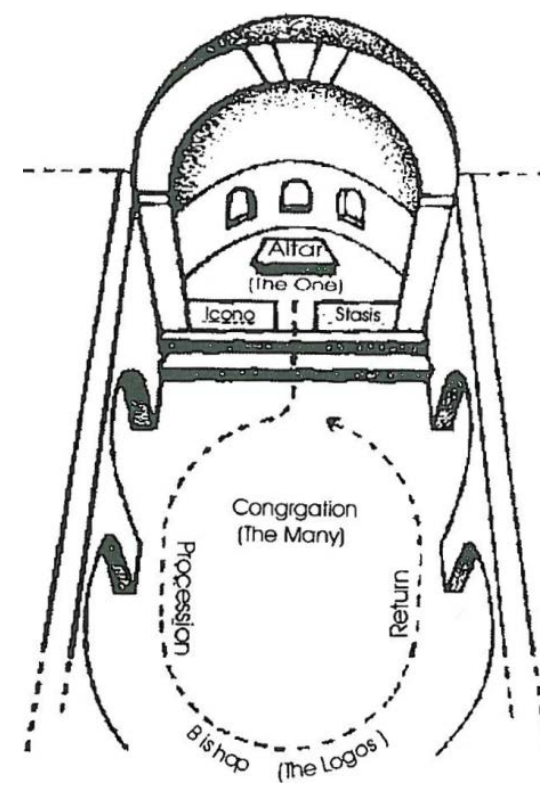

Fig. 1. The pattern of the hierarch's procession from the altar and return to the altar within the plan of a sixth century church. ${ }^{84}$

\section{EARLY CHRISTIAN, BYZANTINE ARCHITECTURE AND THE MEDIEVAL CATHEDRAL LABYRINTH}

The first churches were in houses, regular gatherings would be held in private, the essence of the service was a meal in the dining room. They met daily "and breaking bread from house to house, they ate their food with gladness and singleness of heart" 
(Acts 2:46). By c. 200 AD a clear liturgy had evolved, now that the daily communal meal had become rare and was mostly restricted to funereal and memorial banquets. The regular service consisted of two parts. One part was for both the catechumen, and the faithful. In the second part of the service the catechumen were excluded.

Until the early third century church architecture did not exist. ${ }^{87}$ Eusebius claimed that by 303 AD the crowded assemblies gathered together in every city. With overcrowding came great dissatisfaction with the early church buildings. As a result the Christians began to erect wider and more spacious churches. ${ }^{88}$ After the Edict of Milan in $313 \mathrm{AD}$, which put Christianity on the list of 'tolerated' cults in the Roman Empire, Christians could hold masses and build churches openly. Services were no longer a matter of the simple meal and the reading of the scriptures they became a solemn ceremonial which adapted particular elements of court procedure. ${ }^{89}$

With the rise of the Emperor Constantine and his conversion to Christianity, the church became closely linked with the imperial administration. ${ }^{90}$ Eusebius described a church consecrated at Tyre in 318 AD, at which he delivered the inaugural speech, was a very lavished colonnaded building, a 'royal house'. ${ }^{91}$ The church at Tyre was an early example of a basilica: the word basilica means king's hall. Its general design was a towering, rectangular hall, the length was two to three times the width. In the interior the columns formed one or more aisles on each side. The entrance was on one of the long sides and on the other was the apse, which contained a shrine. ${ }^{92}$ The basilica was found to be a suitable building in which to hold large meetings. ${ }^{93}$

Constantine moved the capital to Byzantine, renaming it Constantinople. With this move Rome's political status declined, and Milan became the political capital in the west from 353 A D. ${ }^{94}$ Ambrose, Bishop of Milan from 374 $\mathrm{AD}$, had considerable spiritual influence and political shrewdness, and for a time he made Milan a powerful centre of ecclesiastical power in the west. ${ }^{95}$ Milan, under Ambrose's guidance, lay the foundations for the new capital's grandiose church architecture. Ambrose and other Church Fathers were influenced in the layout of churches and baptisteries by the symbolic meaning of shapes - and most particularly by the shape and meaning of the octagon. Ambrose wrote of an octagonal baptistery that was near the church of St Thecla at Milan:

Eight-sided is the lofty shine to match its sacred use;

Eight-angled is the font to show its benefits profuse;

With such a number grace and life supplanted human guilt

And with such number must the hall of baptism be built. ${ }^{96}$

The foundations of the baptistery that Ambrose refered to have been excavated under Milan Cathedral: the octagon is approximately twelve metres across, and the font in the centre is also octagonal. ${ }^{97}$ The basilica church with the octagonal or round baptistery became the most common type of church architecture in the Western Roman Empire.

In the east, Byzantine architecture developed a domed covered square. Byzantine 
architecture was predominantly ecclesiastical. ${ }^{98}$ The basilica continued to be used, however, the development of the Byzantine style was partly aesthetic and partly symbolic. The dome was symbolic of the vault of heaven and symbolism permeated Byzantine architecture. ${ }^{99}$

The architectural difference between east and west was due to liturgical requirements. In the Latin mass the priests remained in the apse separated from the congregation in the nave. While in the east, the priests occasionally moved around the congregation but most of the service was held behind the iconostatis, a screen covered with icons, which separates the nave and the apse. ${ }^{100}$ The contrast between the long basilica of the west and the square layout of the eastern churches was found in the liturgy. The focus of the western worshiper was on the altar while the eastern worshiper was more conscious of the all-enveloping presence under the dome, the vault of heaven. ${ }^{101}$ The heavenly related to the earthly, the hierarch who was closest to God and everything was linked back to the heavens. Byzantine architecture was the architecture of the incarnation, and it possessed a very strong dramatic quality. ${ }^{102}$

Although Pseudo-Dionysius's encircling procession of the hierarch enacted the dance of the angels, the illumination of light through the spheres was to enlighten the human hierarchy; this was similar to the eastern Eucharist, but nevertheless had a profound influence in the west. St Gregory the Great (540-604) called Dionysius an "ancient and venerable Father." ${ }^{103}$ In 827 a copy of Dionysius's work was sent by the Byzantine Emperor Michael to the King, Louis the Pious. Hildium, Abbot of St Denis, translated this copy from Greek into Latin. The translation was almost unintelligible and Hildium added a biography of Dionysius. He claimed that Paul had narrated a mystical vision to Dionysius, which Dionysius transcribed, in his work. Hildium further claimed that Dionysius was the first bishop of Paris and the patron saint of his monastery, St. Denis. ${ }^{104 " ~ A l t h o u g h ~ t h e ~}$ translation was soon replaced, the biography remained a point of interest throughout the Middle Ages. ${ }^{105}$ Dante believed that the secret of the angels, as related by Dionysius, was received directly from Paul. ${ }^{106}$ There were a few references to Dionysius in commentaries of the ninth century and works on scholastically theology of the tenth and eleventh century. ${ }^{107}$ The early twelfth century was the turning point for PseudoDionysius in the west. Dionysius influenced writers such as Peter Lombard (11001160), professor of theology in Paris and later Bishop of Paris. Hugh of Saint Victor edited two commentaries on the 'Celestial Hierarchy' between 1125 and 1137. John Sartary of St Denis wrote a commentary in $1140 .{ }^{108}$ Many more commentaries were written in the end of the twelfth and thirteenth centuries. Thomas Aquinas wrote an explanation for several works, he complained about the obscure, confused and confusing language of Pseudo Dionysius yet Aquinas was determined to make sense of it." Saint Bonaventure hailed him as 'the prince of the mystics'110 Dionysius works' influenced the realm of ecclesiology and its link with politics. The ecclesiastical hierarchy was the counterpart in its structure to the celestial hierarchy from this a supporter of the pontifical theocracy concluded, "that the Pope held power over 
all."111 In France of the twelfth century the ecclesiastical and the political hierarchy were not distinct, Louis VII emphasising his episcopal rank.”"112 Under Louis ViI's reign, Abelard, a monk at St Denis, narrowly escaped a trial for treason when he dared to suggest that the Dionysius, the first bishop of Paris and the patron saint of his monastery, St. Denis, was not the same person as Dionysius the Areopagite. ${ }^{113}$ In Hugh of St Victor commentaries he described the human hierarchy as been 'governed' by the images of the angels so the visible hierarchy of men could learn from the invisible hierarchy of the angels. ${ }^{114}$

Abbot Suger of St Denis (1081-1151) explained the symbolism of light, in the basilica that he had built, through the ideas of Dionysius. This basilica was the first abbey in the Gothic style. ${ }^{115}$ The main aspects of Gothic architecture were light and the relationship between appearance and the structure of the building. ${ }^{116}$ These Gothic basilica were the mystically and liturgically image of heaven. The massive windows of the Gothic style filtered light throughout the basilica, the light being muted by the stain-glass windows. However, these stain-glass windows to Suger were analogical to illumination of the divine light of God as described by Dionysius. ${ }^{117}$ The Gothic basilica was the celestial city of the incorporeal world as described in the book of Revelations and Dionysius, and on the floor of many of these basilicas were large dominate labyrinths symbolising the corporeal world. Pseudo-Dionysius's influence spanned both east and west.

St Michele at Pavia is a basilica that was built slowly from c. 1100 AD to 1160 AD. In the chancel, in an area that contains the altar, the seats for the clergy and the choir, was a floor mosaic that contained a labyrinth that dates to the time of the completion of the church. Only part of the labyrinth survives, and was hidden by an altar that was installed in 1592 AD. The labyrinth was round and 3.3 meters in diameter; it had the same structure as the later Chartres labyrinth. Octagonal labyrinths began to appear in the naves of Gothic churches, the successor of Romanesque churches, of the thirteenth century. At Amiens Cathedral the earliest known octagonal labyrinth takes up the entire width of the nave; it is 12.1 metres in diameter and also has the same path pattern to the Chartres labyrinth. The entrance is on the opposite side to the altar so to enter the labyrinth is to face the altar. The three remarkable cathedrals at Arras, ${ }^{118}$ St Quentin ${ }^{119}$ and Reims ${ }^{120}$ contained large octagonal labyrinths in the nave, with the entrances on the western side, opposite the altar. Although many labyrinths are used to illustrate Medieval manuscripts, there are no octagonal labyrinths in these manuscripts. The octagonal shape was purely a development of the labyrinth in churches and their meaning. Although there are many Chartres-style labyrinth in manuscript, none are octagonal in shape. The round labyrinths such as Chartres Cathedral have the same orientation and the same relationship with the altar. Whether round or octagonal, most of the church labyrinths have the same underlying structure in the path pattern.

Medieval records reveal that the clergy danced on some of these labyrinths. The most extensive medieval records on ecclesiastical dance are those of the Auxerre pelota 
ritual. This dance was performed on the floor labyrinth at the Cathedral of St. Stephen at Auxerre at Easter Monday Vespers, that is, at the sunset of Easter Day. ${ }^{121}$ The Bishop of Mende, G. Durandus, late thirteenth century, mentioned that occasionally on Easter and sometimes at Christmas priests and their clerks played ball games accompanied by songs and dances. ${ }^{122}$ The rules and a description of the ball-game dance were preserved in a decree of $1396 .{ }^{123}$

The Dean would gather the canons for Vespers on the floor labyrinth, the newly elected canon would present the Dean with a ball that had to be large enough to be held in both hands. Holding the ball in his left hand the Dean performed a tripudium movement while singing the Easter hymn 'Victimi Paschall laudes'. Meanwhile, the canons joined hands in a Chorea, and danced, circa daedalum, around the labyrinth. As the dance was being performed the Dean would throw the ball back and forth continuously from the Dean to canons and back again. ${ }^{124}$ Unfortunately, how the dance was actually staged is unknown. The dance was described as tripudium and 'garland-like'. ${ }^{125}$ The Dean could have remained in the middle of the labyrinth while the canons, with joined hands, either circled around the outside of the labyrinth or followed the path of the labyrinth in then out. Perhaps the canons could have remained circling the circumferences of the labyrinth while the Dean followed the path throwing the ball as he moved along or turned on the labyrinth floor. Either way, the chain or ring of dancing canons would have been continually broken so they could catch the ball.

Fig. 2. The Chartres labyrinth.

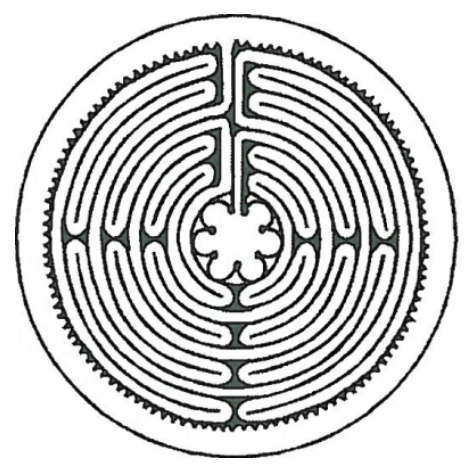

Unfortunately, the Auxerre labyrinth was destroyed for unknown reasons shortly before $1690^{126}$ and with no drawing surviving the structure is unknown. However, it is thought to be similar or the same as the Chartres labyrinth. There is some evidence that Easter dances were performed by clerics during Easter Vespers at Chartres, ${ }^{127}$ in a metropolitan church in Sens, ${ }^{128}$ and Amiens Cathedral. ${ }^{129}$ The bishops of both Auxerre and Chartres were subject to the Archbishop of Sens, and ecclesiastical rituals as well as iconographic architectural features like the labyrinth would be shared among various churches in the archdiocese. ${ }^{130}$

"Where dancing is there is the Devil." ${ }^{131}$ This was the medieval attitude towards 
dance. However, this did not extend to the dance of the angels or the human counterpart, the dance of the clergy. These dances were danced on a labyrinth that consisted of twelve concentric circuits. These twelve circuits of the Medieval labyrinths may have represented the Medieval concept of the Aristotelian universe. The Medieval universe was depicted as twelve spheres; the four elements, the earth, water, fire and air, in the centre then the moon, the sun, the five visible planets and the fixed stars.

\section{CONCLUSION}

Philo described the music and the dance of the celestial spheres and the corporeal dance of the Therapeutics. The Therapeutics dance was a circular dance of a tripartite structure, the danced then they turn to the heavens a prayed for the revelations of the mysteries. In the hymn to Jesus in the Acts of St. John, the dance is a round dance of unknown structure. However, the hymn has celestial references or meanings. The dancers dance to understand the mysteries and the hymn represented the mystery. Through the dance the universe was revealed and the dancer heard the harmony of the spheres. Clement of Alexandria expressed his desire to reveal the mysteries of the Christian faith through the terms of those he was attempting to convert. He claimed that the only true mystery is that of the pure light, which is given only to the initiated this light reveals visions of heaven and of God. Through the revelation of the mysteries, the initiated shall dance with the angels. Clement removed the corporeal cosmic dance and replaced it with the dance of the angels.

The mysteries, to Pseudo-Dionysius, were much more than just a connection of the visible world with the invisible world. These mysteries gave the incorporeal world their shape or pattern in the corporeal world. That shape or pattern was in the form of the sedate dance of the Hierarch performing the Holy Eucharist. The Hierarch mimicked the dance of the angels. Their purpose was to pass the light onto the initiated or through the spheres, respectively.

Christian church architecture, east and west developed its own layout to suite the liturgical needs. The western Church architecture moved toward the basilica and the octagon baptistery, while the Eastern Church moved toward the square covered domed style. The contrast between the long basilica of the west and the square layout of the eastern churches was in regards to the liturgy. The western worshipers' focus was on the altar while the eastern worshiper was more conscious of the all-enveloping presence under the dome, the vault of heaven.

By the twelfth century, Pseudo-Dionysius's dance of the nine spheres of the angels was accepted as the vision of St Paul and Dionysius hailed as 'prince of the mystics'. Although the dance of the hierarch did not became part of the western Eucharist, its ritual symbolism was accepted, and this can be seen in great writers such as Peter Lombard and Dante, and by painters such as Botticelli.

The canons and the Dean danced the tripudia a ceremonial ball dance around the labyrinth at Auxerre Cathedral. As they danced they sung a hymn in glory of the 
Resurrection, to celebrate Christ's victory over the devil. The shape, whether octagonal or round, of the labyrinth is unknown but it was positioned in the nave of the Cathedral, ${ }^{132}$ and presumably it would have been a similar size to the other church labyrinths built at the time which took up the entire width of the nave. The octagonal shape of some of the church labyrinths and the hymn sung by the dancers at Auxerre further underlined the connection of the resurrection with the Medieval labyrinth. The typical structure of the floor labyrinth with the same structure as the Chartres labyrinth symbolised the spheres of the corporeal universe. To follow the pattern of these large labyrinths is to encircle the labyrinth, halt and then encircle the labyrinth in the opposite direction, to move though the labyrinth is to turn - halt counter-turn. In short, the cathedral labyrinths have a tripudia structure to the centre. Furthermore, the position of the labyrinths and the altar, all imply than the Auxerre dance was a successor of Pseudo-Dionysius' cosmic dance of the human hierarchy, mimicking the cosmic dance of the angels, which was a successor to a far more ancient cosmic dance. The Christian mysteries transcended the mere natural and entered into the realm of the incorporeal through the symbols of the corporeal. Words like rebirth have many different meanings in terms of belief and culture. However, they are often clothed in much the same language, and enacted in many similar types of rituals.

\section{NOTES}

${ }^{1}$ Clement, "The Exhortation to the Greeks," in G. W. Butterworth (ed.), Clement of Alexandria (London: William Heinemann Ltd. XII, 1953).

${ }^{2}$ Backman, E. L., Religious Dances in the Christian Church and in Popular Medicine (London: George Allen \& Unwin Ltd., 1952), pp. 44-50.

${ }^{3}$ Dante, The Divine Comedy Vol. III: Paradise (New York: Penguin Books. XIV, 1986), pp. 40-45.

${ }^{4}$ Pseudo-Dionysius, Pseudo-Dionysius: The Complete Works (Mahwah: Paulist Press, 1986), p. 208a.

${ }^{5}$ Philo, "On the Account of the World's Creation Given by Moses," in F. H. Colson (ed.), Philo (London: William Heinemann Ltd., 1949), p. ix.

$6 \quad$ Ibid., p. $X$.

${ }^{7}$ Eusebius, The Ecclesiastical History (London: William Heinemann Ltd., 1949), p. 11, xvi. Philo, "On the Acount of the World's Creation Given by Moses."

9 Ibid., p. 48.

${ }^{10}$ Ibid., p. 51.

11 Ibid., p. 52.

${ }^{12}$ Ibid., p. 53.

13 p. 54.

${ }^{14}$ Ibid, pp.70-71

${ }^{15}$ Ibid

${ }^{16}$ Ibid., p. 78. 
${ }^{17}$ Ibid., p. 89.

${ }^{18}$ Ibid., p. 102.

${ }^{19}$ Ibid., p. 105.

${ }^{20}$ Ibid., p. 95.

${ }^{21}$ Ibid., p. 126.

${ }^{22}$ Ibid., p. 100.

${ }^{23}$ Ibid., p. 125.

${ }^{24}$ Ibid., p. 70.

25 Philo, "The Contempletive Life," in F. H. Colson (ed.), Philo (London: William Heinemann, 1954), pp. 112-171.

${ }^{26}$ Ibid., p. 32.

${ }^{27}$ Ibid., p. 22.

${ }^{28}$ Ibid., pp. 18-20.

${ }^{29}$ Ibid., p. 2.

${ }^{30}$ Ibid., pp. 24-29.

${ }^{31}$ Ibid., pp. 30-33.

${ }^{32}$ Ibid., p. 65.

33 Ibid., pp. 83-84.

${ }^{34}$ Ibid., p. 89.

${ }^{35}$ Eusebius, Ecclestiastical History, II, p. xvi.

${ }^{36}$ Ibid., II, p. xvii.

${ }^{37}$ Ibid., II, p. xviii.

${ }^{38}$ Pulver, M., "Jesus' Round Dance and Crucifixion According to the Acts of St. John," in J. Campbell (ed.), The Mysteries (New York: Princeton University Press, 1978),pp. 169-193, p. 169. Ibid., p. 170.

${ }^{40}$ Pagels, E., "To the Universe Belongs the Dancer," Parabola, 1979, Vol. 4(2), pp. 7-9, p. 7.

${ }^{41}$ James, M. R., The Apocryphal New Testament (Oxford: Clarendon Press, 1975), Acts of St. John, pp. 94-96.

${ }^{42}$ Backman, E. L., Religious Dances in the Christian Church and in Popular Medicine (London: George Allen \& Unwin Ltd., 1952), p. 15. Pulver, 1978, p. 177.

${ }^{44}$ Ibid., p. 173, Backman, 1952, p. 14.Acts of St John, p. 98.

${ }^{46}$ Ibid., p. 101.Augustine, Letters 204-270 (Washington: The Catholic University of America Press,1956), letter 237.

${ }^{48}$ Ibid, p. 8.

${ }^{49}$ Miller, J., Measures of Wisdom: The Cosmic Dance in Classical and Christian Antiquity (Toronto: University of Toronto Press, 1986), p. 101; Pulver, 1978, p. 173.

${ }^{50}$ Clement, Exhortation to the Greeks, XII.

51 Ibid. " Ibid.

${ }^{53}$ Pseudo-Dionysius, "Mystical Theology," 1033c.

${ }^{54}$ Pseudo-Dionysius, "The Celestial Hierarchy," 208a.

${ }^{55}$ Pseudo-Dionysius, "The Divine Names," 704d.

${ }^{56}$ Pseudo-Dionysius, "Letters." p. 1104c. 
${ }^{57}$ Ibid., 1105c.

Ibid., 1108c.

${ }^{60}$ Pseudo-Dionysius, "The Ecclesiastical Hierarchy," 425c.

${ }^{61}$ Ibid., 425b.

${ }^{62}$ Ibid., 396b-d.

${ }^{63}$ Ibid., 508a.

${ }^{64}$ Ibid., 536d.

${ }^{65}$ Ibid., 533a.

${ }^{66}$ Ibid., 537a.

${ }^{67}$ Ibid., 396d.

${ }^{68}$ Ibid., 436a.

${ }^{69}$ Ibid., 433d.

${ }^{70}$ Ibid., 433c.

71 Ibid., 433a.

72 Ibid., 432d-433a.

${ }^{73}$ Ibid., 396a.

${ }^{74}$ Ibid., 396b.

${ }^{75}$ Ibid., 396c-d.

${ }^{76}$ Ibid., 396d.

${ }^{77}$ Ibid., 424d-425a.

${ }^{78}$ Ibid., 425d.

${ }^{79}$ Ibid., 429a.

${ }^{8 \circ}$ Ibid., 432a.

${ }^{81}$ Pseudo-Dionysius, "The Celestial Hierarchy," 212a.

${ }^{82}$ Ibid., 208a.

${ }^{83}$ Pseudo-Dionysius, "The Ecclesiastical Hierarchy," 425b.

${ }^{84}$ Miller, 1986, p. 517.

${ }^{85}$ Ibid., 444a.

${ }^{86}$ Ibid., 441d.

${ }^{87}$ Krautheimer, R., Early Christian and Byzantine Architecture (Middlesex: Penguin Books, 1986), p. 42.

${ }^{88}$ Eusebius, The Ecclesiastical History (London: William Heinemann Ltd., 1949), VIII,

p. 1 .

${ }^{89}$ Milburn, 1988, p. 86.

${ }^{90}$ Krautheimer, 1986, p. 38.

${ }^{91}$ Eusebius, The Ecclesiastical History, 10.39.

${ }^{92}$ Milburn, 1988, pp. 86-87.

93 Ibid., Krautheimer, 1986, p. 41.

94 Ibid., pp. 68 and 78,

95 Ibid., Milburn, 1988, p. 111.

${ }^{96}$ Milburn, 1988, p. 206.

${ }^{97}$ Ibid. 
${ }^{98}$ Hamilton, 1986, p. 39.

99 Ibid., p. 28.

${ }^{100}$ Hamilton, 1986, p. 29.

${ }^{101}$ Ibid., p. 80.

${ }^{102}$ Ibid., p. 278.

${ }^{103}$ Luibheid, 1987, p. 26.

${ }^{104}$ Miller, 1986, p. 520.

${ }^{105}$ Ibid., p. 521.

106 Dante, The Divine Comedy, Vol. III: Paradise (New York: Penguin Books, 1986), XXVIII, pp. 136--137.

${ }^{107}$ Luibheid, 1987, p. 27.

${ }^{106}$ Ibid., pp. 27-28.

${ }^{109}$ G. G., "Dionysius the Pseudo-Areopagite Gnostic Myth," in E. R. Elder (ed.),

The Spirtualitv of Western Christendom (Oxford: Cistercian Publications Inc., 1978), p. 36.

${ }^{110}$ Ibid., p. 36.

${ }^{111}$ Luibheid, 1987, p 30.

${ }^{112}$ Simson, 0. V., The Gothic Cathedral (Princeton: Princeton University, 1988), p. 139.

${ }^{113}$ Ibid., p. 106.

${ }^{114}$ Ibid., p. 139.

${ }^{115}$ Ibid., p. 64,

${ }^{116}$ Ibid., p. 3.

${ }^{117}$ Ibid., pp. 120-122.

${ }^{118}$ Ibid., p. 150.

${ }^{119}$ Ibid., p. 162.

${ }^{120}$ Ibid., p. 160.

${ }^{121}$ Doob, 1985, p. 134.

122 See footnote 4, Chambers, E. K., The Medieval Stage (London: Oxford University Press, 1903), pp. 128-129.

${ }^{123}$ Backman, 1952, p. 67.

${ }^{124}$ Ibid. and Doob, 1985, p. 134.

${ }^{125}$ Ibid.

${ }^{126}$ Kern, 2000, p. 150.

${ }^{127}$ Ibid., p. 147.

${ }^{128}$ Backman, 1952, p. 75.

${ }^{129}$ Doob, 1990, p. 123.

${ }^{130}$ Doob, 1985, p. 134.

${ }^{131}$ Doob, P. B. R., The Auxerre Labyrinth (The Myriad Faces of Dance, University of New Mexico, Society of Dance History Scholars, 1985), p. 134.

${ }^{132}$ Ibid., p. 134. 